\title{
China Faces the World: Making Rules for a New Order?
}

\author{
Gerald Chan
}

Published online: 21 June 2013

(C) CEEUN 2013

\begin{abstract}
Does China's diplomatic practice create norms and rules that shape the behaviour of other states? To what extent do other states follow China's examples in international affairs? I argue in this paper that China's diplomatic practice does pose a real and credible challenge to the practices established by the West in managing global affairs. The paper tests this argument by analysing China's involvement in the areas of peacekeeping, the Six-Party talks, China's maritime security, and its development practice. Initial results from this analysis indicate that China has initiated some new norms and rules, but their effects are small and gradual at present.
\end{abstract}

Keywords China - Rules · World order - Peacekeeping - Six-Party talks · Maritime security $\cdot$ Development

Does China's diplomatic practice create norms and rules that shape the behaviour of other states? To what extent do other states follow China's norms and practices in international affairs? To answer these questions, this paper assesses the growing policy impact of a rising China on global governance and the subsequent implications for International Relations study. I argue that China's present diplomatic practice poses a real and credible challenge to the practices established by the West (Europe and the US) in managing global affairs since the birth of the Westphalian system in the seventeenth century and more recently since the end of the Second World War.

This challenge coincides with China's increasing engagement with the world in various fields. Although the challenge is still relatively small in scale and is unlikely to overturn any time soon the existing global order, its significance, however, lies in

G. Chan (ه)

Department of Political Studies, University of Auckland, Auckland, New Zealand

e-mail: gerald.chan@auckland.ac.nz 
the emergence of an observable trend. This trend shows a shift of China's role from a passive adherent to the existing global order to an increasingly participatory and, to some observers, aggressive stakeholder in the international system. In this way, China has sown the seeds of change for some of the ground rules governing the existing order.

The hypothesis put forward here is that: in an effort to promote its national interests, China has inadvertently and inevitably challenged the existing norms and rules that govern inter-state relations, inducing some countries to modify their original compliance behaviour to these norms and rules so as to please Beijing. This paper aims to test this hypothesis by analysing China's involvement in four issue areas: (1) its increasingly active participation in UN peacekeeping activities, including the recent case of Darfur; (2) its hosting of the Six-Party talks to tackle North Korea's nuclear crisis; (3) its emerging policy and practice in maritime security; and (4) its model of development which challenges the traditional mode of development.

These four issue areas are chosen to highlight China's major security and development concerns. They impinge critically on its national interests as North Korea is an ideologically close ally and a geo-strategically close neighbour, while Darfur presents a pivotal case to demonstrate China's contributions towards international peacekeeping and the 'China model' shows its path to development which is so different from that of the West. Maritime security carries long-term implications for China's goal of becoming a militarily strong and economically rich country. The control of sea-lane communication is vital to China's foreign trade, its acquisition of natural resources abroad to fuel its industry, and the protection and promotion of its economic links with various parts of the world. The relative decline of American power and the potential rivalry between the US and China in world affairs mean that free and safe shipping communication now provided by the US cannot be fully taken for granted in future.

These four issue areas provide a fertile ground for examining China's development of its soft power, as oppose to the use of hard power such as the use of force to settle international disputes. China's peacekeeping activities provide a test case for China's extension of its soft power of peaceful rise. Its heavy involvement in the Six-Party talks provides a test case for examining its soft power in conflict resolution. Its maritime security policy and practice provides a test case for determining its soft power in distributing and sharing resources. And its model of development provides a test case for assessing its soft power in global development and the spread of wealth.

The critical focus in studying these four issue areas is the potential creation of new ways to deal with global problems and new rules to govern relations among states. These creativities and practices, in which China plays a vital role as an initiator, if repeated elsewhere and accepted by other countries, may constitute a new paradigm in international diplomacy.

This paper will use the empirical evidence found in the four cases to affirm or refute the above hypothesis: that China challenges the rules and norms of global governance through its diplomatic practice. In addition, the paper has an academic aim of stimulating the growth of a new understanding of international relations that 
challenges and revises conventional thinking. This project is part and parcel of a growing interest in and awareness of the relevance of Chinese contributions to the creation of new international thinking.

The paradigm shift alluded to here seems to be starting to emerge. Its process would seem neither sudden nor short-lived. Rather, it is likely to be slow and incremental, but diffused and widespread. This paper charts the changes in this process that cumulatively help to put together what I call, for lack of a better term, 'Sino-globalism' or 'global governance with Chinese characteristics'. In sum, this paper, representing a first cut in this research focus, suggests that a new paradigm is in the making.

\section{China's UN Peacekeeping}

China has actively participated in UN peacekeeping activities, in particular its contributions in Darfur, Sudan, where its human rights record has been severely criticised by Western observers. China, however, has succeeded in creating new norms of international intervention, centring on the involvement of a relevant regional organisation, in this case the African Union, as an important condition to be satisfied before the authorisation of the act of intervention. This condition complements other conditions such as the tacit approval of the UN Security Council, the consent of the host country, and the minimal use of force by intervening power(s).

The Darfur case stands out as a watershed in China's approach to intervention. ${ }^{1}$ What makes this case distinct is China's much more active involvement in Darfur, compared with previous cases of serious human rights abuses such as Rwanda and Kosovo. China's active involvement has led to its adoption of some new practices and policies, one of which is the required participation of pertinent regional organisations in the process of conflict resolution. Using content analysis to compare the three cases of Rwanda, Kosovo and Darfur, Wu Chengqiu of Fudan University in Shanghai has pointed out, however, that China's understanding of state sovereignty and non-intervention has not changed much. ${ }^{2}$ Chinese diplomats have fiercely defended the principles of non-interference in the internal affairs of others and the preservation of state sovereignty. Official statements reinforce such a stand. Chinese new President Xi Jinping's denunciation of domestic interference and new interventionism is a case in point, a denunciation made in his speech in Moscow on his first official visit overseas in March 2013 since taking office.

What seems to have changed is the Chinese discourse on human rights issues, which has shown greater willingness to engage in human rights dialogues, followed by more active diplomatic activities in dealing with cases of humanitarian crisis. In the case of Darfur, the reason for such active involvement can be found in China's defence of its material interests there, the securing of oil being cited as one of the main interests. Sudan exports some seventy per cent of its oil to China. Why China

\footnotetext{
1 See Lee et al. (2012).

2 Wu (2010).
} 
changed its approach to intervention from Rwanda and Kosovo to Darfur is not entirely clear, as the Chinese decision-making process in this and other foreign affairs is shrouded in secrecy. The linkage between the Chinese increasing discussions on human rights and its increasing involvement in cases of humanitarian crises is largely circumstantial and correlational rather than causational. The fact that China, through its Information Office of the State Council, has published a large number of white papers on human rights, does not show a direct linkage to practice, as some critics of China's human rights record have pointed out that these publications and dialogues on human rights issues between Chinese officials and their overseas counterparts are primarily used to deflect outside criticisms of its poor human rights record and of shielding China from taking necessary measures to make improvements in the human rights area.

Another example that demonstrates China's expressed condition of peacekeeping or intervention can be found in the Libya case. It was with the agreement of the Arab League that the Chinese government accepted UN sanctions against Libya and connived with the interventions carried out by France and the UK into the country which eventually led to the collapse of the Libyan government and the death of its leader Colonel Gaddafi in 2011. In fact, the dramatic events that happened in Libya took the Chinese government by surprise. China and Libya had formed a strong relationship under Gaddafi with Chinese investors and labourers poured into the country in search of oil and in building the infrastructure of Tripoli. As local opposition forces gathered momentum and Western investments began to pull out of the country ahead of NATO's military action, China sent ships to evacuate its own citizens, leaving a lot of investments behind. China continued to support Gaddafi in his defiance against the West. However, at a late stage, China also started contacts with the main opposition regime, the National Transition Council, being the last permanent member of the UN Security Council to do so. In maintaining its principle of non-interference, China did vote with the West in sanctioning Libya in the UN only when the Arab League gave up on Gaddafi. It did not side with Russia's call on Gaddafi to step down at a G8 meeting, as such action would violate its principle of non-interference. It watched on helplessly the bombardment by NATO forces, led mainly by French and British air raids on the Gaddafi forces.

China's non-interference or non-intervention policy can be traced back to its adherence to the Five Principles of Peaceful Coexistence since the 1950s. ${ }^{3}$ To this day, Chinese government officials still refer to these five principles as a fundamental guide for all countries to conduct international relations. ${ }^{4}$ One of these principles is the non-interference in the internal affairs of other countries. China's commitment to non-intervention has come under increasing challenge since 1979 when the country started to engage increasingly with the outside world. In order to protect its overseas interests, to moderate its policies with those of other countries and international organisations, and to project its image as a responsible power in the

\footnotetext{
${ }^{3}$ This and the following sections are a slightly revised and updated version drawn from Chan (2011). The five principles are: (1) mutual respect for sovereignty and territorial integrity; (2) nonaggression; (3) noninterference in each other's internal affairs; (4) equality and mutual benefit; and (5) peaceful coexistence.

${ }^{4}$ For example, the five principles were emphasised by Hu Jintao at China's 11th Ambassadorial Conference held in July 2009. See Glaser (2009).
} 
international community, China has modified its traditional adherence to noninterference. This is especially so when China acts under the auspices of the United Nations and, in some cases, under those of regional organisations like the African Union and the Arab League, in dealing with issues of security threats, crisis management, and natural disasters which threaten to endanger the security and stability of neighbouring countries by the target country under intervention.

Two major features stand out in China's policy in this area of (non-) intervention. ${ }^{5}$ One is China's increasing confidence and assertiveness, ${ }^{6}$ as a result of its rising power and its accumulated experience in global diplomacy. Coupled with the changing international environment after the Cold War, China has become less apprehensive of potential outside interference in its internal affairs by other countries. It has therefore become more relaxed and less stringent on adhering to the non-interference principle; it has in fact accepted a certain kind of limited, conditional interference. However, China stops short of endorsing the idea of 'Responsibility to Protect' championed by Western countries when facing situations of gross violation of human rights on a massive scale such as genocide, ethnic cleansing, war crimes, or crimes against humanity. China insists on securing the sanction of the UN Security Council as a prerequisite for intervention, to be guided by the UN Charter. It also emphasises the need to involve regional organisations in dealing with regional issues. More importantly China adheres to the principle that crises which warrant intervention must have posed a security threat to neighbouring countries in the first place. Based on this principle, China is against external intervention in the affairs of Myanmar and Zimbabwe, which are regarded by the Chinese government as internal matters. ${ }^{7}$

Another interesting feature that concerns intervention is a recent move by China to despatch two warships to Somali waters in early April 2009, entering into what some Chinese commanders said as a 'stage of orderly replacement and normalisation. ${ }^{8}$ These two warships were scheduled to rotate and replace two other ships which were sent in December 2008 to patrol the Gulf of Aden in order to combat pirate activities that threatened the safe passage of commercial shipping. This is the first time that China has sent naval vessels to go beyond its home shores to join a multilateral force in order to clamp down pirate activities in the high seas. This Chinese move seems to be based on a rational choice that:

- China acts to protect its commercial and security interests;

- It acts in response to the UN call to mount a multilateral force to combat piracy in the area;

- It can acquire valuable operational experiences through multilateral coordination in naval patrols; and

- It enhances its image as a responsible power in global affairs.

\footnotetext{
5 Pang (2009).

${ }^{6}$ For an assessment of how assertive China is, see Johnston (2013).

7 See, for example, the analysis of Pang, 'China's non-intervention question'.

${ }^{8}$ Cui (2009).
} 
A rather surprising development came about in May 2011. At a conference in Washington DC, a Chinese general is reportedly to have said that the land haven of these pirates should be attacked so as to eradicate their activities at sea. Some observers suggest that the Chinese have become frustrated by the lack of a more permanent solution to the problem as pirate activities escalate. Others say that the general's view is a mere propaganda rather than anything of substance as the Chinese lack the capability to mount a successful land attack, as other countries, including the US, do not seem to have the appetite for taking such a move. ${ }^{9}$ Addressing the UN tenth plenary meeting of the contact group on piracy off the coast of Somalia in November 2011, Wang Min, China's deputy permanent representative to the $\mathrm{UN}$, said that military action was not the final solution. He stressed the importance of adopting a comprehensive solution that involved political dialogues to establish political stability, economic and social development. He also stressed the importance of the input by regional organisations such as the African Union. He indicated that China had so far provided US\$2.2 million cash to the African Union Peacekeeping Operation in Somalia, and five million yuan $(\$ 780,000)$ to Uganda and Burundi to be used for purchasing logistical supplies to support the two countries' participation in the African Union Mission in Somalia. ${ }^{10}$ By the end of October 2011 China had despatched ten batches of twentysix warships to patrol the Gulf of Eden.

An interesting question ensues from these developments: To what extent has China changed its non-interference policy? China is now in the midst of transition from a strict, traditional adherence to non-interference to a limited, conditional one. The conditions under which China acts may change over time according to changing circumstances. If China continues to open up and integrate with the world, as it is likely to do in the foreseeable future, the country is likely to involve more in interventions of one kind or another. However, one can also see that China has not forsaken entirely its non-interference policy as it still emphasises the importance of the mutual respect of state sovereignty, given the fact that it continues to face a host of external and domestic challenges to its rule and legitimacy. China continues to adopt a largely Westphalian view of interpreting the UN Charter, in contrast to the more progressive interpretations by scholars and policy makers in the West who are prone to take interventionist measures to deal with humanitarian crises, for various political and moral reasons. The gap between China's position and the position of the liberal West is still very wide.

\section{The Six-Party Talks}

China's hosting of the Six-Party talks to tackle North Korea's nuclear ambition offers an interesting test case: is it possible to replicate this multilateral approach to deal with other Asian security problems, where China has a stake? The likely expansion of the membership and the widening of the mandate of the Shanghai

\footnotetext{
9 Bodeen (2011).

${ }^{10}$ Xinhua (2011).
} 
Cooperation Organisation may mirror some of China's approaches towards the management of the Six-Party talks (6PT). Also, the dispute over the sovereignty of some small groups of islands in the South China Sea involving China and a number of countries in Southeast Asia may serve as a test case to see if China's conflict resolution model developed in Northeast Asia can be applied to dealing with conflicts in Southeast Asia. In particular, whether or not China is willing to change its bilateral approach (its preference) to a multilateral approach (preferred by the Southeast Asian countries under ASEAN as a group) to handle this dispute. In addition, how China is going to settle the territorial disputes with Japan and South Korea, its strong neighbours in Northeast Asia, will be fundamental to the building up of Asia-Pacific region as a peaceful, stable, and prosperous region.

The 6PT provide a sharp focus for examining China's dispute resolution approach. As a permanent member of the United Nations Security Council, China has a great-power responsibility to settle international disputes through its good offices. This is a responsibility that other countries expect China to fulfil and a responsibility that China realises that it has to fulfil as a veto power in the UN Security Council. ${ }^{11}$ As North Korea is a bordering country with a close relationship since the days of the tributary system in pre-modern times, China has an added interest in seeing that this regional security issue to be handled properly. The North Korea case becomes a rare case of critical importance in security, not only in Northeast Asia, but further afield.

China started to act as a go-between to host the talks in 2003. In September 2005 the six parties (China, North Korea, South Korea, Japan, Russia, and the US) reaffirmed the goal of achieving a verifiable denuclearisation of the Korean peninsula in a peaceful manner through negotiation. In October 2006 the North Koreans surprised all, including the Chinese, by conducting an underground nuclear test. The UN Security Council adopted Resolution 1718 demanding North Korea 'not [to] conduct any further nuclear test or launch ... a ballistic missile.' ${ }^{12}$ All members of the Security Council, including China, appealed to Pyongyang to 'abandon all nuclear weapons and existing nuclear programmes in a complete, verifiable and irreversible manner.' ${ }^{13}$ After five rounds of talks with numerous hiccups, in 2007 North Korea agreed to shut down its nuclear facilities in exchange for fuel aid and opportunities to normalise relations with the US and Japan. The agreement allowed North Korea to return to the Nuclear Non-Proliferation Treaty.

North Korea conducted its second nuclear test in May 2009, which placed China in an awkward position once again. The Security Council passed Resolution 1874 condemning the nuclear test and calling on North Korea not to conduct any additional nuclear test. Beijing agreed to support and to implement the resolution. In July 2009 North Korea formally withdrew from the 6PT. In November 2009 US

\footnotetext{
11 See Yang (2013).

12 Security Council strengthens sanction on Democratic People's Republic of Korea. Security Council, SC/10934, 7 March 2013. http://www.un.org/News/Press/docs/2013/sc10934.doc.htm (Accessed 9 April 2013).

13 Security Council tightens sanction on DPR Korea in wake of latest blast. UN News Centre. http://www.un.org/apps/news/story.asp?NewsID=44313\&Cr=democratic\&Cr1=korea (Accessed 9 April 2013).
} 
special envoy Stephen Bosworth visited Pyongyang, which marked the beginning of official bilateral talks. Pyongyang took more provocative steps in 2010: in March it was alleged to have sunk the Cheonan, a South Korean navy corvette, in the Yellow Sea; in November North Korea shelled Yeongpyeong Island, causing South Korean civilian casualties. After the shelling, China appealed for the resumption of the 6PT for an emergency consultation. To China's disappointment, the US held joint military exercises with both South Korea and Japan to show their anger and their determination to deter North Korea.

When Kim Jong-il died unexpectedly on 17 December 2011, news from Seoul suggested that North Korea agreed to suspend uranium enrichment in exchange for American food aid of up to 240,000 tons. ${ }^{14}$ The suspension is one of the conditions that the US has set for the resumption of the 6PT. In late 2010 North Korea expressed its willingness to return to the 6PT without pre-conditions, after a visit to Pyongyang by Dai Bingguo, Hu Jintao's envoy. In response to the third nuclear test by North Korea in February 2013, China registered its official objection to North Korea's action. Calling on all sides to keep calm and to dialogue, China again called on the resumption of the 6PT to settle the dispute.

The 6PT can be seen as a Chinese initiative to counter the US dominance in Northeast Asia, as the US has forged strong military ties with Japan and South Korea. China's increasing role in handling the North Korean nuclear issue can also be seen against the background of the US pre-occupation (although in decline) with its military campaigns in the Middle East (Iraq, Iran) and Central Asia (Afghanistan), allowing China some room to play an active role in managing the conflict in Korea. American top officials have, in fact, praised China for playing a constructive role there. China has been put in an extremely difficult situation on a number of occasions, as it has to work with an often erratic, bellicose, and reckless North Korea. By being sympathetic to North Korea's plight, China sometimes exposed itself to the danger of being held hostage to its neighbour's demand. At the same time, it earned the wrath of the US and its allies of being too soft on North Korea. At other times, North Korea chastised China for being submissive to the West. All throughout, it is safe to assume that North Korea tries to strike out an independent path of its own, for its own interests. It wants to negotiate directly with the US, ignoring South Korea and Japan and side-lining China and Russia. China, on the other hand, has the largest assets in dealing with and influencing North Korea, as China is the only ally of North Korea, supplying most of the needed food, fuel, trade, and diplomatic support.

\section{China's Maritime Security}

Recent developments in China's maritime policy and practice have exposed some of the uncertainties found in the United Nations Convention on the Law of the Sea. International controversies are likely to occur over the creation of new norms and

\footnotetext{
14 N. Korea "agrees to suspend uranium enrichment". 17 December 2011. http://www. mysinchew.com/node/67940 (Accessed 18 December 2011).
} 
rules by China in dealing with the freedom of navigation in international waters and the rights of states in Exclusive Economic Zones. This is the case especially in those rights relating to naval navigation and to scientific research and surveillance conducted by military ships.

Can a country's navy operate in the exclusive economic zones (EEZs) of another country? China says no, while the US has gone to great lengths to preserve its 'right' to do so. In July 2010 the US and South Korean naval forces held joint military exercises in the waters off South Korea after blaming North Korea for torpedoing a South Korean warship, the Cheonan, in March that year. Initially the military drills were to be conducted in the Yellow Sea between the Korean peninsula and China. While the 1982 United Nations Convention on the Law of the Sea, to which China is a signatory country while the US is not, does not stipulate explicitly whether foreign military ships can operate in a country's EEZ of 200 nautical miles, China has argued that the Convention is not applicable to military vessels and vehemently protested against the conducting of the exercises in the Yellow Sea. ${ }^{15}$ On the one hand, the US made tacit concessions to China by relocating the July 2010 drills to the Sea of Japan, further away from the Yellow Sea near China's coast; ${ }^{16}$ on the other, apprehensive of setting a precedent that could impair its naval manoeuvrability, the US refused to fully yield to China's demand. As a show of defiance, the US announced weeks later that it would conduct another exercise with South Korea in the Yellow Sea. However, the most noteworthy feature of the second exercise was that the US scaled it down by not involving the more threatening nuclearpowered aircraft carrier, the USS George Washington. ${ }^{17}$ As Daniel Blumenthal, a former US defence official, has noted, 'As [China] grows more powerful, it desires to change international rules written when it is weak'. ${ }^{18}$ Apparently-and with limited success - China wants to lay down a new international 'soft' rule, which requires that foreign military ships to refrain from operating in the EEZ of a coastal state without the consent of the latter, while the US is resistant to completely play by this new informal rule. ${ }^{19}$

In a recent review of China's assertive behaviour in the South China Sea, Michael D. Swaine and M. Taylor Fravel say that China has maintained all along a

\footnotetext{
15 See Articles 56 and 58 of the United Nations Convention on the Law of the Sea of 10 December 1982. http://www.un.org/Depts/los/convention_agreements/texts/unclos/closindx.htm (Accessed 29 July 2010). Major General Luo Yan of the People's Liberation Army's Academy of Military Sciences points out that the drill area is only $500 \mathrm{~km}$ (270 nautical miles) from Beijing. See Yan (2010).

16 Spegele (2010a, b).

17 Initially the US planned to deploy the USS George Washington to the Yellow Sea in the second exercise in September 2010. But later the government changed its mind. See Li and Cafarello (2010). 'Yellow Sea drill involves no aircraft carriers: US,' Agence France Presse, 20 August 2010, through Factiva. The plans for another military exercise in October 2010 in the Yellow Sea that would have involved the aircraft carrier were cancelled ahead of a G20 summit meeting in Seoul in November 2010. See Huang (2010).

18 Blumenthal (2010).

19 Maritime powers, particularly the US, have long been opposed to coastal states' quest for expanding their jurisdictions seawards beyond the territorial waters. What is significant now is that it is China, a strong candidate for world power, rather than the traditional 'territorialists' such as Brazil and Peru that challenge the US. Boczek (1988), Pedrozo (2010).
} 
basic strategy consisting of two aspects: (1) avoid conflict while defer the resolution of the dispute in favour of negotiation and cautious management (sometimes involving notable concessions); (2) keep a resolute defence against perceived attempts by other countries to undermine its diplomatic, legal, political, economic, and military position. ${ }^{20}$

These developments in Sino-US encounter in sea activities have ramifications far beyond one or two independent incidence. The US relies on the greatest sphere of freedom of movements and actions to maximise its control, power, and interest around the world. China's rise means that on the one hand, it can hardly resist from breaking out of the restriction or containment embedded in America's maritime policy. On the other, China sees the need to expand its naval presence in areas of its expanding activities, acting not unlike any other rising powers, past and present. How the two superpowers and other stakeholders handle this potential confrontation is of crucial importance to regional and global peace and stability. Several areas may present themselves as useful test cases to understand this development: China's near coast; the South China Sea; China's lane of sea transportation to the Middle East; and China's naval patrol in the sea off the East African coast. In each of these areas of activities, China's rule-making potentials and behaviour, their impact on the other states and stakeholders, and the subsequent responses are yet to be charted.

\section{China's Model of Development}

China's model of development has attracted the attention of many Third World countries, in particular those in sub-Saharan Africa. China offers a programme of aid and development that privileges the building of economic and social infrastructure and the satisfaction of basic human needs such as food and shelter. China offers assistance without imposing harsh 'good governance' conditions demanded by donors and organisations in the West. In this way China's programme differs markedly from the formula of the OECD or the conditions set by the World Bank and the IMF. Subsequent to the global financial crisis of 2008-2009, neoliberal economics has come under criticisms seldom seen before. A paradigm change gathers momentum, shifting from free-market capitalism to state-managed capitalism. To what extent has South-South cooperation promoted by China and the BRICS countries changed the traditional model of global development?

The spectacular economic growth of China in the past 30 years or so has prompted the suggestion that a China model is in the making. Journalist turned academic analyst Joshua Cooper Ramo has helped to popularise such a model under the title 'Beijing Consensus'. Whether a China model exists or not is subject to some debates. However, if we can identify or define the essential features of a model, and if most seasoned observers agree with and recognise those features, then we can safely assume that the model exists. It is on this basis that we treat the socalled China model. What then are the essential features of the China model? Alvin So of the Hong Kong University of Science and Technology suggests five features:

\footnotetext{
${ }^{20}$ Swaine and Fravel (2011).
} 
(1) fast-speed economic growth; (2) export-led industrialisation; (3) innovation and technological upgrading; (4) poverty reduction; and (5) independent and autonomous development. ${ }^{21}$ One can see that So's first characteristic is very much the result of the successful working of the model rather than a factor leading to its success. Likewise, poverty reduction is very much a policy adopted by the government to address the uneven distribution of wealth as a result of fast economic growth. Apart from these five features, one can add at least two more: statecontrolled capitalism, as opposed to free-market capitalism championed by neoliberal preachers and practitioners; and the work ethics of the Chinese, that is, sheer hardworking. As observed by Howard French, a journalist turned academic in the US who has had substantial working experiences in China and Africa: '...they [the Chinese] come to make it in Africa. And they're not leaving until they do....they're going to work 20 hours a day till they make it....22

So's understanding of the China model is but one among many others. For example, Chen Minglu and David S.G. Goodman, writing recently in the Journal of Contemporary China, ${ }^{23}$ cite six authors who harbour different approaches to the understanding of the China model from different perspectives: they see different aspects and dynamics of China's development experience. Of these, Joshua Cooper Ramo mentioned earlier, is most optimism and flamboyant about the Beijing Consensus, singing praises about China's essence of success even to the embarrassment of some Chinese analysts and officials. Giovanni Arrighi surprises his readers by undermining the conventional wisdom that Adam Smith is representative of the free market, pure and simple. To Arrighi, Smith would also condone some state control of the market in China. Martin Jacques, another optimist who looks favourably at China's development success, suggests that China would rule the world and it would be only a matter of when. ${ }^{24}$ Stefan Halper, a former US official turned academic, takes a look at the Beijing Consensus and sees China as a threat to US hegemony. ${ }^{25}$ Zhao Suisheng points out that the economic development in China in future depends on political reform, a view shared by many analysts, both inside and outside of China. Barry Naughton, however, looks deepen into China's conditions of development such as the size and scale of its market, public and private ownerships, and industrial policies and reforms. Sarah Cook, a development economist not discussed in the Chen and Goodman article, sums up the essence of the China model well: it 'is one of pragmatism, experimentation, and gradualism, looking for successes, keeping what works, and discarding what does not. ${ }^{26}$ All these observations remind us of the famous Indian parable of the six blind men coming to grips with the look of an elephant by touching different parts of the animal to draw their own images of the elephant.

\footnotetext{
21 So (2011).

22 'Howard French on Africa in a Chinese century.' http://www.radioopensource.org (Accessed 19 July 2011).

23 Chen and Goodman (2012).

24 Jacques (2012).

25 Halper (2010).

26 Quoted in So, 'Development model,' p. 18.
} 
Different observers, seeing China's experiences, unique or otherwise, under different lights, come to different conclusions as to the applicability of the China model to others. Much depends on the model learners: which features to take in, which to reject, and which to modify, adapt, and apply. At least two features are likely to be more prominent: one is the building of social and physical infrastructure such as rails, roads, hospitals, schools, and the odd but grand sport stadiums-these are fundamental building blocks to further economic and social development; the other is a good mix of the state-market structure to suit the authoritarian or democratic style of the country concerned or the taste of its leaders.

\section{Discussing the Four Cases}

What sort of norms have China initiated? Are these norms followed by other countries? If yes, to what extent? If no, why is that the case? The Darfur case provides some interesting clues. As a result of China's active involvement in trying to settle the conflict in Darfur as well as between the north and the south of Sudan and as a result of the lack of political will on the part of the West to actively resolve the conflict, China was able to forge a settlement based on three levels: at the local level, the consent of the host government was obtained, in this case, the Omar alBashir government in Khartoum; at the regional level, the African Union was involved in peacekeeping and conflict management; and at the global level, the United Nations gave its sanction. ${ }^{27}$ While the consent of the local government and the sanction of the UN are not new as they formed the basic principles of traditional peacekeeping operations, the active involvement of a pertinent regional organisation has set a relatively new benchmark. This Darfur case differs from the previous case of Rwanda, where the Organisation of African Unity, the predecessor of African Union, was more or less dysfunctional; or the case of East Timor, where the ASEAN countries shied away from involving in conflict settlement, leaving Australia to take the lead.

Is China interfering in the internal affairs of North Korea through the 6PT? To some North Korea observers, China may have interfered in the internal affairs of North Korea, especially in considering its very strict interpretation of the nonintervention principle. Engagement with a view to resolving a serious dispute is perhaps a better way of understanding the situation. In this sense, it may be viewed as a conditional or limited intervention for peaceful purposes. Whether China's effort in running the 6TP can be regarded as a success or failure is subject to different interpretations. The fact that North Korea is not unequivocally committed to the non-development of nuclear weapons and the continuation of its erratic onagain, off-again behaviour towards dialogue can be seen as the failure of the 6TP. However, the fact that North Korea has not entirely shut off from negotiation (through exchange of bargains, threats, or deterrence) and that no war has broken out during the process of the talks can be seen as a success of the 6PT. At present (as of March 2013) the talks are stalled, but it does not mean that they will not be

\footnotetext{
${ }^{27}$ For details, see Lee et al. (2012).
} 
Table 1 New rules in the making? (a first cut)

\begin{tabular}{|c|c|c|c|c|}
\hline & UNPKO & $6 \mathrm{PT}$ & Maritime security & 'China Model' \\
\hline Principles & $\begin{array}{l}\text { Non-intervention } \\
\text { (modified) }\end{array}$ & $\begin{array}{l}\text { Dialogues; } \\
\text { negotiations; } \\
\text { bargaining }\end{array}$ & $\begin{array}{l}\text { Protection and } \\
\text { promotion of } \\
\text { national interests }\end{array}$ & $\begin{array}{l}\text { 'Work hard, lie } \\
\text { low' (Deng } \\
\text { Xiaoping) }\end{array}$ \\
\hline Rule making & $\begin{array}{l}\text { Involvement of } \\
\text { regional } \\
\text { organisation }\end{array}$ & Non-use of force & $\begin{array}{l}\text { Abide by the Law of } \\
\text { the Sea }\end{array}$ & 'State capitalism' \\
\hline $\begin{array}{l}\text { Rule } \\
\text { enforcing }\end{array}$ & $\begin{array}{l}\text { Through UNSC } \\
\text { resolutions }\end{array}$ & $\begin{array}{l}\text { Maintain links, quiet } \\
\text { diplomacy }\end{array}$ & $\begin{array}{l}\text { Negotiations } \\
\text { (verbal }+ \text { military } \\
\text { build-up) }\end{array}$ & $\begin{array}{l}\text { By persuasion, soft } \\
\text { power; 'he' } \\
\text { (harmony) }\end{array}$ \\
\hline $\begin{array}{l}\text { Behavioural } \\
\text { change by } \\
\text { others }\end{array}$ & $\begin{array}{l}\text { Accept UN } \\
\text { resolutions; } \\
\text { join or support } \\
\text { regional efforts }\end{array}$ & $\begin{array}{l}\text { N. Korea wants direct } \\
\text { talks with US; } \\
\text { others subscribe to } \\
\text { China's role }\end{array}$ & $\begin{array}{l}\text { Balancing; } \\
\text { bandwagoning; } \\
\text { coalition building }\end{array}$ & $\begin{array}{l}\text { Welcomed by Third } \\
\text { World; neo- } \\
\text { liberal order } \\
\text { under challenge }\end{array}$ \\
\hline
\end{tabular}

resumed in a renewed form when conditions allow, or they may take the form of separate bilateral or three-way talks. Whether the glass is half empty or half full is a dilemma typical of analysing the North Korea case.

As China rises in power and its overseas interests expand, there is a felt need by Chinese decision makers to reach out to protect and promote those interests, like many rising powers before China. China's maritime security comes to the fore of China's priorities in foreign and military policies. How China would behave and how others would respond is likely to create a space for the contestation of rules governing maritime security around China's expanding sphere of influence.

In international development, China does not go about deliberately making rules for others to follow. China does things its own way, according to its own circumstances. It does things by exemplifying rather than by laying conditions in politically intrusive ways, even when it extends aid and investments to the Third World. It is for others, aid donors or aid recipients, to learn from China's experience. In this way, it can be seen that China is making soft rules rather than hard rules, in comparison to the way development aid and investments are being extended by the West.

Table 1 summarises the essence of principles involved in China's engagement with the four areas of UN peacekeeping, the Six-Party talks, its maritime security, and its model of development. It highlights the rules, although rudimentary, that China has initiated, and the accompanying enforcement of those rules. The behavioural changes of countries targeted by the rules represent the evidence that sheds light on the slight shifting of world order suggested in this paper.

\section{Conclusion}

This paper offers as an alternative route to the search for an understanding of Chinese international relations from the Chinese perspective, especially in the way in which Chinese scholars have tried to theorise Chinese international relations. The 
effort to develop international relations with Chinese characteristics and the debates surrounding whether there is such a thing or whether it is worth pursuing such a development has led to little advancement in International Relations studies from the Chinese side. The apparent deadlock to such a path of academic endeavour has many plausible explanations. Instead of mulling over such issues and struggling through along the traditional path with little prospective returns to the growth of knowledge, this paper ventures to take a different, if not an opposite path, that is, to examine China's practical diplomacy in the current context of China's rise in global prominence. The purpose is to deduce from practices in such context a pattern of behaviour in world politics that might throw some light on how we understand and theorise Chinese international relations. To provide a focus, this paper has chosen to pay attention to four areas of interest with a view to assess whether China's behaviour in practice has generated any new norms and rules in global governance which help to shape the behaviour of other states and which induce them to follow or abide by such norms and rules in their foreign policy behaviour. The initial results derived from the analysis in this paper suggest that this is the case, although the changes so far have been small and gradual.

Acknowledgments This paper was originally written for presentation at the 5th World Forum on China Studies held in Shanghai, 22-24 March 2013. I am grateful to the forum organisers, including the organisers of my panel-my friends and colleagues in the School of International Relations and Public Affairs at Fudan University. I have benefited from my panel discussants and other participants for their comments and criticisms. The final revision was done while I was visiting the Department of Politics and Public Administration at Hong Kong University in early April 2013. I want to thank the Department as well as Fudan's School for their generosity in hosting me.

\section{References}

Blumenthal D (2010) The US stands up to China's bullying. Wall Str J Online. http://online.wsj.com/ article/SB10001424052748703700904575391862120429050.html (Accessed 28 July 2010)

Boczek BA (1988) Peacetime military activities in the Exclusive Economic Zone of third countries. Ocean Development and International Law No. 19, pp 445-468

Bodeen C (2011) China calls for attacking Somali pirate base. Associated Press. http://www.foxnews. com/world/2011/05/21/china-calls-attacking-somali-pirate-bases/ (Accessed 9 April 2013)

Chan G (2011) Chinese foreign policy: sixty years on. In: Chan L-H, Chan G, Kwan F (eds) China at 60: global-local interaction. World Scientific, Singapore, pp 21-23

Chen M, Goodman DSG (2012) The China model: one country, six authors. J Contemp China 21(73):169-185

Cui X (2009) 2nd batch of warships head to Somali seas. China Daily. http://www.chinadaily.com.cn/ china/2009-04/03/content_7646462.htm (Accessed 10 April 2009)

Glaser BS, Benjamin Dooley, 'China's 11th ambassadorial conference signals continuity and change in foreign policy. China Brief, Jamestown Foundation

Halper S (2010) Beijing consensus. Basic Books, New York (Halpe is an academic based at Cambridge University)

Huang C (2010) Scrapping of joint exercise shows Sino-US ties warming, through LexisNexis

Jacques M (2012) When China rules the world, 2nd edn. Penguin, London

Johnston AI (2013) How new and assertive is China's new assertiveness? Int Secur 7(4):7-48

Lee PK, Chan G, Chan L-H (2012) China in Darfur: humanitarian rule-maker or rule-taker? Rev Int Stud 38(2):423-444

Li X, Cafarello NT (2010) US aircraft carrier heads for Yellow Sea. China Daily. http://www. chinadaily.cn/world/2010-08/07/content_11114261.htm (Accessed 7 Aug 2010)

Pang Z (2009) China's non-intervention question. Global Responsib Protect 1(2):237-252 
Pedrozo R (2010) Preserving navigational rights and freedoms: the right to conduct military activities in China's Exclusive Economic Zone. Chin J Int Law No 9:9-29

So AY (2011) Development model. In: Tay WS, So AY (eds) Handbook of contemporary China. World Scientific, Singapore, pp 3-4

Spegele B (2010) US, China avoid tiff over plans for naval exercises off Korean coast. Wall Street J Online. http://online.wsj.com/article/SB10001424052748703394204575368110456298760.html (Accessed 28 July 2010)

Spegele B (2010) A sea change in US-China naval relations. http://blogs.wsj.com/chinarealtime/ 2010/07/17/a-sea-change-in-us-china-naval-relations (Accessed 10 April 2013)

Swaine MD, Fravel MT (2011) China's assertive behaviour-part two: the maritime periphery. China Leadership Monitor 35:14

Wu C (2010) 'Sovereignty, human rights, and responsibility: changes in China's response to international humanitarian crisis. J Chin Polit Sci 15:71-97

Xinhua (2011) China says military action not final solution to Somali piracy

Yan L (2010) Why China opposes US-South Korean military exercises in the Yellow Sea. People's Daily Online

Yang SX (2013) China in UN Security Council decision-making on Iraq. Routledge, London, p 187 